\title{
On the Issue of Sociality of Regional Development Strategies
}

\author{
Elena A. Morozova 1[ORCID 0000-0003-2215-9808], \\ Sofia O. Nazarenkova 1[ORCID 0000-0002-9504-3630], \\ Natalia M. Egorova ${ }^{1 *[O R C I D}$ 0000-0002-0075-3542], \\ Anna V. Mukhacheva 2[ORCID 0000-0002-3720-4969]
}

\author{
${ }^{1}$ Kemerovo State University, Kemerovo, Russia \\ ${ }^{2}$ Yaroslav-the-Wise Novgorod State University, Veliky Novgorod, Russia \\ gukkkk@nextmail.ru
}

\begin{abstract}
The study is aimed at analyzing the sociality of regional socio-economic development strategies. In any of them, economic and social components can be distinguished. The social part is usually understood as a target one, aimed at meeting the various needs of the population, and the economic part as providing, creating conditions for the implementation of the former. The social aspect of strategies is expressed through the goals and development plans of either branches of the social sphere (health, culture, education, social protection, leisure, sports, etc.), or social policy, which has similar directions, or constituent elements of the quality of life. With different target interpretations, we are talking about similar social tasks - increasing incomes of the population, ensuring an increase in life expectancy, strengthening health, creating a comfortable living environment, improving sports, leisure and cultural infrastructure, developing a system of upbringing and education, supporting vulnerable categories of the population, ensuring security, etc. Analysis of the Strategy for the socio-economic development of the Kemerovo region - Kuzbass for the period up to 2035 showed the priority of social attitudes in formulating the region's mission, interests and principles to be realized. But with the concretization of development directions through priorities, the economic bias of the strategic document began to manifest itself to a greater extent. At the same time, it was found that the actual social problems of the territorial community in the long term are not fully taken into account. This was confirmed by the results of a study of the public opinion of Kuzbass residents and an assessment of the expert community, which included poor medical care, unemployment and difficulties in finding a job, a low standard of living of the population, poor ecology, etc., among the most important problems for the region.
\end{abstract}

Keywords: strategy, socio-economic development, social policy, social sphere, quality of life

\section{INTRODUCTION}

Scientists, and after them the practitioners, have long agreed upon the thesis that the socio-economic development of territories should be carried out in accordance with strategic goals, with an understanding not only of the near, but also of longer-term prospects. Currently, documents of a strategic nature are adopted at all levels of government - state, regional, municipal.

Strategies for the socio-economic development of regions are of particular interest, since they occupy an intermediate position in strategic management. They should take into account, on the one hand, state priorities and resources, and on the other, local opportunities and perspectives, ensuring the continuity of all levels of strategy.

As the name suggests, there are two planes in regional socio-economic strategies, two sections social and economic. They are closely interrelated and interdependent, sometimes they are clearly divorced in strategic documents, and sometimes closely intertwined. But, in any case, there is a social component in the strategic plans, although its role, 
place, mechanisms and conditions for implementation are articulated in different ways. This is evidenced by the publications of foreign and Russian specialists studying the specifics of regional strategizing, social development and the formation of social policy for territories.

First of all, researchers note that the strategic social policy of the regions depends on the level of development of the country as a whole and the severity of specific problems. In particular, in emerging market economies (Brazil, India, China, South Africa), strategies and programs have been developed and are being implemented to pay transfers, reduce intraregional income inequality, and protect jobs and employment [1]. This policy is very important because economic growth does not guarantee an improvement in the quality of life for the entire population with a minimum time lag.

L. Tillin and A.W. Pereira in their study discuss examples of regional social policies in Brazil and India, emphasizing that the complication of the configuration of the structure of public administration can negatively affect the achievement of national strategic goals, for example, building a welfare state due to the lengthening of the decisionmaking process, political competition for resources. In Brazil and India since the early 2000s the process of transferring responsibility for social policy to the localities (states) went differently. In Brazil, the center of gravity of social policy was gradually centralized, while in India, on the contrary, subnational governments received more powers, including in the area of their strategic development. Today, the unevenness of social policy from state to state in India is very high, the regions remain "states within a state" [2].

Research by E. Pino and H. Ramos demonstrates that serious regional differentiation of social policy is inevitable even in unitary states, although a certain level of social protection and social benefits should be provided to any citizen [3].

The federal states of Germany have broad powers in the social sphere. Thus, Berlin and Bavaria differ significantly in the construction of educational systems and approaches to cultural policy, which is due to their historical experience, value and political orientations of the inhabitants [4]. In developing countries (if we do not take individual federal states), on the contrary, regional powers are limited and they do not pursue an independent social policy [5].

At the same time, modern foreign studies emphasize the globalization of social policy, a decrease in the degree of influence of even independent states on social processes (not to mention individual regions). In the context of the erosion of the "welfare state", the regions, even in developed countries, are often forced to follow the path of reduction in budgetary spending on social needs, abandoning any strategy for the development of human capital [6].

Thus, the problems of regional social policy in the global scientific agenda are not ignored, but they have been studied unevenly. Most often, social policy is viewed through the prism of political relations between the center and the regions, as a result of a certain interaction between levels of government and attempts to increase political popularity. The influence of various national and regional factors on approaches to subnational social policy is discussed. However, little attention is paid to the administrative and economic problems of the social policy of the territories. The resource potential, costs, goals and results achieved by various regions have not been fully explored. In addition, in the foreign literature, the social policy of the regions is little connected with the problems of strategy; it has not been sufficiently studied as part of a long-term development policy.

Russian researchers actively analyze the issues of regional social policy, social development of territories, socio-economic strategies [7-11], but there are not many works devoted to the study of the social aspects of strategic regional documents. As a rule, the social policy of the region is considered outside the strategic context. In recent years, an understanding has come that regional strategies should balance economic, social, and environmental goals, however, the "sociality" of documents for long-term development is practically not studied, which determines a problematic field for its study.

In the course of this study the authors raise such research issues as the place of social issues in the strategies of the regional level, the forms of its reflection in strategic documents, the degree of correspondence of promising goals, objectives, directions to the real social problems of the territories.

\section{MATERIALS AND METHODS}

The aim of the study was to analyze the level of sociality of regional strategic development programs. For its implementation, a number of research tasks were solved: substantiation of the 
feasibility of identifying and substantiating the social components of subfederal strategies; study of the degree of reflection in the basic elements of the regional strategy of the Kemerovo region - Kuzbass (mission, vision, priorities, etc.) of social aspects; analysis of the opinions of the population and the expert community on the importance of regional social problems.

The methodological basis of the study was the works of Russian and foreign scientists in the field of strategic management, social development of territories, and social policy. The following regulatory documents were used as an information base for the analysis: Federal Law No. 172 "On Strategic Planning in the Russian Federation" dated June 28, 2014 and the Strategy for the SocioEconomic Development of the Kemerovo Region Kuzbass for the Period up to 2035 [12, 13].

In addition to traditional theoretical research methods, empirical techniques were used in this work: document analysis, secondary analysis of sociological data, expert method. So, to determine the degree of sociality of the regional strategy, firstly, a substantive assessment of the main provisions of the relevant document was carried out. Secondly, the data of two regional public opinion polls were analyzed (the first took place in December 2018 and covered 1000 people according to a representative regional sample; the second - in April 2021 with a sample size of 1500 people). Thirdly, expert surveys were carried out aimed at identifying the correspondence of strategic objectives to the real problems of the territory (in October-November 2020, 70 experts were interviewed, which included scientists, representatives of business, state and municipal administration, non-profit organizations, executives of social sphere).

\section{RESULTS}

The sociality of strategic development programs should be understood as the level of attention in them to urgent problems of a social nature, directions for improving the functioning of social sectors, measures related to social policy. First of all, it is necessary to determine which aspects of the life of the regional community are social, since in addition to traditional spheres and activities (education, health, culture, sports, leisure, social protection), the notion "social" sometimes includes ecology, housing and communal services, road infrastructure, communications and information support, law enforcement, social and labor sphere, consumer services. In our opinion, all of the listed components should be considered social, since they are aimed at meeting the various needs of people and directly affect the quality of their life.

In accordance with paragraph 29 of Art. 3 of the Federal Law "On Strategic Planning in the Russian Federation", "the strategy of socio-economic development of the constituent entity of the Russian Federation is a strategic planning document that defines the priorities, goals and objectives of public administration at the level of the constituent entity of the Russian Federation for the long term”. Art. 32 specifies that the regional strategy contains "priorities, goals, objectives and directions of the socio-economic policy of the constituent entity of the Russian Federation". Based on this, in the main strategic document of the region it is necessary to assess, first of all, the basic priorities, goals, objectives and directions. If they are predominantly social in color, then the strategy should be characterized as socially oriented. If other attitudes (economic, environmental, production, etc.) are strategically balanced with social ones, it can be recognized as a strategy with an average level of sociality. If the strategy is dominated not by social, but by other problems, it should be attributed to documents with a low level of sociality.

This division is arbitrary and does not mean that some version of the strategy is better, but some is worse; it only states the level of reflection of social issues in a promising document. It is important to emphasize that social strategic tasks are superstructure, their implementation, of course, depends on the economic base. However, economic development should not be an end in itself, it is a tool for achieving social prospects. Therefore, it is necessary to ensure the maximum balance, harmony of economic and social projects.

As an example, consider the Strategy for the Socio-economic Development of the Kemerovo Region - Kuzbass for the Period up to 2035 (hereinafter - the Strategy). Its priorities, goals and objectives, as well as initiatives are discussed in the second section of the document, which begins with a statement of the mission, slogan, vision and fundamental components of the Strategy.

"The mission of the Kemerovo region - Kuzbass focuses on ensuring a full and decent quality of life for Kuzbass residents and guests of Kuzbass, the effective implementation of national interests and priorities of Russia, localized in the region, regional priorities of Kuzbass and all of Siberia". The first part of the mission statement is clearly social in 
nature, since it is about the quality of life of people; the second part deals with national and regional development priorities, among which, no doubt, there are also social projects.

After formulating the mission, the document says that the implementation of the Strategy "will provide a new social dynamism in the developing region, maintain and strengthen the education of youth in the spirit of patriotism, resilience, tolerance, mutual assistance, benevolence and enterprise - the wonderful qualities of people with a Siberian character", thereby strengthening the social orientation of the Strategy, emphasis is placed on its educational effect. The mission of the Kemerovo region - Kuzbass is presented in a short form of the slogan: "Kuzbass - Siberian character and creation".

The vision in the strategic document is represented by the interests pursued, the principles of the Strategy and its priorities. The implemented interests are formulated as follows: "Kemerovo Region - Kuzbass aims to implement the interests, material and intellectual needs of the residents of the region, national interests and priorities of Russia, the Siberian Federal District, localized in Kuzbass, directly the interests of the regional business community, which correspond to the interests and priorities of all enterprises, institutions and organizations of Kuzbass". Just as in the mission, the first part of this thesis has an obvious social emphasis, since there is an appeal to the interests and needs of residents (however, only the material and intellectual needs of people are named). The second part is mixed, and in this case the interests of the business community in general and economic entities in particular are emphasized.

The principles of the Strategy are, as a rule, of a mixed socio-economic form: safety and reliability; quality of life, products and services; digitalization and smart specialization; openness to society and markets; leadership in grounded spheres of economy, science, culture, sports, tourism.

Two principles can be classified as predominantly social: social responsibility, environmental friendliness and public health; to predominantly economic - one: financial stability and security.

Further, the Strategy outlines the priorities: Kuzbass - a region with a decent life for people; strategic security of Kuzbass; strategic diversification of the Kuzbass economy; strategic development of Kuzbass life support systems (water supply and sewerage); strategizing of foreign economic, scientific, educational, cultural, sports ties and international cooperation; strategizing the scientific and technological potential of Kuzbass and digitalization of the regional economy; strategizing of the financial system of Kuzbass.

Based on the analysis of the outlined priorities, which are described in more detail in the next part of the strategic document, the second, fourth and fifth contours can be attributed to the mixed orientation option; to the predominantly economic - the third, sixth and seventh; and to the predominantly social only the first. Thus, when the Strategy is detailed, its content is reoriented to the economic and production plane.

Let us briefly present the first group of priorities, which was classified as social. It includes the following priorities: "Kuzbass is a center of professional excellence", "Kuzbass is a center of high quality of life of the population", "Kuzbass is a center of decent work", "Kuzbass is a center of new competencies and jobs for a green economy". Each of the priorities is fleshed out through plans to create more private centers. Thus, the Strategy mentions "center for high quality of life of the population including: a center for the development of social services; health development center; family development center; center for the development of culture and state ethnic policy; center for the provision of geriatric services; active leisure center; center for the development of physical culture and sports in Kuzbass; a center for providing the population with affordable and comfortable housing in Kuzbass".

The basic targets and priorities of the regional strategy showed that the mission, interests and principles of the strategy have a social bias, but its directions (priorities) mostly affect the economic sphere. This situation cannot be considered anomalous in essence, since, as already noted, an economic base is needed to solve social problems, which confirms another provision of the Kuzbass document, which is set out after the list of priority contours: “... Strategy-2035 will lead to a radical improvement in environmental and social living conditions in Kuzbass on the basis of the implementation of breakthrough point projects that will radically improve the social and economic climate of Kuzbass, fundamentally change the negative trend of population outflow from the region that has developed earlier".

The analysis of the strategic document at the regional level can be deepened by considering other official materials, first of all, the plan for the 
implementation of the regional strategy. However, it is also important to understand how this or that regional strategy is aimed at solving social problems that are urgent for the territory, since, being predominantly social in its content, it can overlook some serious and acute issues.

To solve the corresponding problem, the best option is to conduct sociological research and determine the attitude, on the one hand, of experts, on the other, of the population, to the general socioeconomic situation in the region and its individual aspects, including managerial ones. It is advisable to track these issues in dynamics, to record trends of changes, to study expectations and opinions on the prospects for the development of the region.

Thus, Kuzbass surveys in 2021 showed that 59\% of the region's population are completely satisfied or rather satisfied with their lives, and $34 \%$ are completely or rather not satisfied. About a quarter of the region's residents highly rated the socioeconomic situation in Kuzbass, while two-thirds of citizens gave low ratings. Slightly less than a third of the population $(30 \%)$ is optimistic about the threeyear future of their native region, pessimists make up $22 \%$, and $36 \%$ of adults believe that the socioeconomic situation in the Kemerovo region will not change in the coming years.

As for the opinions of the residents of the region about specific social problems, they were studied in December 2018. The following were identified as the most relevant: low standard of living of the population (it was noted by $47 \%$ of respondents); unemployment, employment problems $(43 \%)$, poor medical care (39\%); high level of drug addiction and alcoholism (33\%); poor performance of passenger transport (28\%); poor environmental situation (28\%); poor work of housing and communal services (27\%); low level of economic development (23\%); disorder of children's and adolescent leisure time (20\%); garbage collection problems (17\%). Thus, in the top 10 problems of the greatest concern to the population, there are 9 social ones, which indicates a high level of severity of difficulties of this particular type.

In addition to public opinion, in the fall of 2020 in the Kemerovo region, expert assessments of the socio-economic state of the region as a whole and the state of affairs in various spheres and industries were studied. Experts assessed the general situation in the region slightly higher than the population: high ratings (very and rather) were given by almost a third of the respondents, low - by almost two-thirds. When assessing the state of economic sectors and spheres of life in Kuzbass, the experts were most critical of the environment, healthcare, employment, small business and entrepreneurship, the standard of living of the population, wages, the economy in general, the media, industrial production, and the social sphere in general. Thus, 7 out of 10 most problematic sectors are social, which also testifies to the primacy of the social agenda. It should be noted that experts, assessing the changes that have occurred in Kuzbass over two years, in most cases gave negative comments about the development of the health care system, the standard of living of the population, ensuring employment, environmental safety and the development of entrepreneurship. In other areas of activity, there were more positive assessments than negative ones.

The topical social problems identified by the population and experts for the most part were reflected in the strategic document, although the degree of their relevance is not fully taken into account (for example, the most problematic sphere healthcare - did not receive due attention in the Strategy). A number of assessments by experts who expressed their opinion on the strategic regional plan using a five-point scale also testify to the insufficient elaboration of topical issues. Thus, according to the criterion "The level and depth of analysis of real problems, competitive advantages and opportunities for the development of the region", the experts put an average of 3.69. The criterion "The degree of taking into account in the strategy global, national, industry, corporate trends and interests" was rated 3.52, the criterion "The degree of realism, consistency, validity of goals, priorities and projects of the strategy" - 3.31, the criterion "Compliance of the strategy with the needs (expectations) of the region's population" -3.27 .

\section{DISCUSSION}

As already noted, the strategic planning of the socio-economic development of the regions is based on the legal and methodological foundations contained in the Federal Law "On Strategic Planning in the Russian Federation". However, Russia has not yet adopted a strategy for the socio-economic development of the federal level, which violates the general logic of the development of regional documents of this type, including their social components. In a sense, the state strategy is replaced by national goals and strategic objectives, initiatives of socio-economic development, for example, adopted in May 2018, in July 2020, in October 2021 [14-16], but they do not have the form of a common 
system document and cannot fully represent the country's strategy. This and similar problems are pointed out by scientists analyzing approaches to strategizing in Russia [17-19].

The relevance and content of various social problems at the regional level, in particular, in the Kemerovo region - Kuzbass are analyzed by many scientists [20-22], including the authors of this article [23-25], emphasizing the close relationship between the economic and social factors of the development of the territory. However, few authors substantiate the necessity and expediency of reflecting objective social contradictions and acute problems in regional strategic documents.

One cannot but agree with Yu.N. Svinukhova, who, considering the issues of social development of the region, notes the limitations of economic determinism, when economic development becomes the center of the strategy, and social development and an increase in the quality of life are postulated as an inevitable consequence [26]. In modern conditions, economic growth does not automatically determine social progress; therefore, the social development of the region must be strategized separately.

Based on the foregoing, the attempt of the authors of the publication to show the importance of the social component of the territorial strategy, the forms of its reflection in a prospective document, possible approaches to assessing the representation of social problems in it is justified.

\section{CONCLUSION}

In the theory and practice of regional socioeconomic strategizing, the task is to adequately balance social and economic priorities and areas of development of territories. However, so far there are no acceptable approaches to determine the harmony of the corresponding vectors of promising changes. The authors made an attempt to approach the solution of this problem by analyzing the Strategy of socio-economic development of the Kemerovo region - Kuzbass for its sociality.

The mission of the region, the interests pursued and the principles of the Strategy are predominantly social in nature, which cannot be said about the contours of priorities. Only one of the seven contours can be attributed to social, three - to economic, three - to mixed, i.e. when detailing longterm goals, the economic bias of the strategic document is manifested.
When forming a strategy, it is important to take into account urgent social problems, the assessment of which is advisable to carry out by studying the opinions of the population and experts. In Kuzbass, most of the population is satisfied with their lives, but assesses the socio-economic situation in the region mostly negatively, and among the acute problems most often names social ones: low living standards of the population, employment problems, poor medical care, etc.

Experts assessed the socio-economic situation in the region slightly higher than ordinary residents, but negative assessments prevail among them as well. They named the environment, health care, employment and others as the most problematic sectors and spheres in Kuzbass.

Thus, despite the social nature of the formulations of the target settings of the regional strategy, its content, revealed through the development priorities, does not fully take into account the actual social problems of the region.

In the course of the analysis, the research goals and objectives were solved, and the practical significance of the work was indicated. On the one hand, it consists in substantiating the need to take into account the objective social problems of the regional community as fully as possible in strategic documents, and on the other hand, to balance social and economic priorities, directions of development, specific projects.

\section{AUTHORS’ CONTRIBUTIONS}

The authors made an equal contribution to the study: collection and analysis of material; definition of goals and objectives, research methods; formulation and scientific substantiation of conclusions, registration of key research results in the form of an article.

\section{REFERENCES}

[1] L. Tillin, J. Duckett, "The politics of social policy: welfare expansion in Brazil, China, India and South Africa in comparative perspective", Commonwealth \& Comparative Politics, 2017, vol. 55(3), pp. 253-277. DOI: 10.1080/14662043.2017.1327925

[2] L. Tillin, A.W. Pereira, "Federalism, multi-level elections and social policy in Brazil and India", Commonwealth \& Comparative Politics, 2017, vol. 55(3), pp. 328-352. DOI: $10.1080 / 14662043.2017 .1327928$ 
[3] E. Pino, H. Ramos, "Is welfare retrenchment inevitable? Scope and drivers of healthcare reforms in five Spanish regions during the crisis", Journal of Social Policy, 2018, vol. 47(4), pp. 701-720. DOI: $10.1017 / \mathrm{S} 0047279418000077$

[4] C. Schultz, H. Kolb, "Managing cultural diversity in Federal Germany: Bavaria and Berlin as Classic antagonists", Fédéralisme Régionalisme, 2015, vol. 15.

[5] I. Mares, M. Carnes, "Social policy in developing countries", Annual Review of Political Science, 2009, vol. 12, pp. 93-103. DOI:

10.1146/annurev.polisci.12.071207.093504

[6] E.D. Aravacik, "Social policy and the welfare state", Public Economics and Finance, 2018. DOI: $10.5772 /$ intechopen.82372

[7] L.E. Ilyicheva, A.V. Lapin, "Strategies for the socio-economic development of regions in terms of national goals and priorities. Political analysis: Monograph" [Strategii sotsial'noekonomicheskogo razvitiya regionov $\mathrm{v}$ rakurse natsional'nykh tseley i prioritetov. Politicheskiy analiz: Monografiya], Moscow: Aspect Press, 2021, 272 p. (In Russ.).

[8] F.E. Karaeva, R.V. Shumakhov, "Social aspect of sustainable development of the region", Bulletin of Samara Municipal Institute of Management, 2019, vol. 4, pp. 34-41. (In Russ.).

[9] L.G. Cherednichenko, R.V. Gubarev, E.I. Dzyuba, F.S. Fayzullin, "Social development forecast for Russian regions", Finance: Theory and Practice, 2018, vol. 22(5), pp. 132-152. (In Russ.). DOI: 10.26794/25875671-2018-22-6-132-152

[10] V.V. Klimanov, K.V. Budaeva, N.A. Chernyshova, "Preliminary results of strategic planning in Russian regions", Economic Policy, 2017, vol. 12(5), pp. 104-127. (In Russ.). DOI: 10.18288/1994-5124-2017-506

[11] A.F. Sukhovey, I.M. Golova, "Differentiation of innovative development strategies of regions for improving the effectiveness of socio-economic policy in the Russian Federation", Economy of Region, 2020, vol. 16(4), pp. 1302-1317. (In Russ.). DOI: 10.17059/ekon.reg.2020-4-20

[12] Government of the Russian Federation, Federal
Law "On Strategic Planning in the Russian Federation" [O Strategicheskom Planirovanii v Rossiyskoy Federatsii] (June 28, 2014, No. 172FZ). Moscow, 2014. (In Russ.). Retrieved from http://www.kremlin.ru/acts/bank/38630/page/5

[13] "The Strategy of Socio-economic Development of the Kemerovo Region - Kuzbass for the Period up to 2035" [Strategiya Sotsial'noekonomicheskogo Razvitiya Kemerovskoy Oblasti - Kuzbassa na Period do 2035 Goda]. (In Russ.). Retrieved from https://кузбасс2035.pф

[14] President of the Russian Federation, Decree "On National Goals and Strategic Objectives of the Development of the Russian Federation for the Period up to 2024" [O Natsional'nykh Tselyakh i Strategicheskikh Zadachakh Razvitiya Rossiyskoy Federatsii na Period do 2024 Goda] (May 7, 2018, No. 204). Moscow, 2018. (In Russ.). Retrieved from http://www.kremlin.ru/acts/bank/43027

[15] President of the Russian Federation, Decree "On the National Development Goals of the Russian Federation for the Period up to 2030" [O Natsional'nykh Tselyakh Razvitiya Rossiyskoy Federatsii na Period do 2030 Goda] (July 21, 2020, No. 474). Moscow, 2020. (In Russ.). Retrieved from http://www.kremlin.ru/acts/bank/45726

[16] Government of the Russian Federation, Order "On approval of the list of initiatives for the socio-economic development of the Russian Federation until 2030" [Ob Utverzhdenii Parenchyma Initsiativ Sotsial'noekonomicheskogo Razvitiya RF do 2030 Goda] (October 6, 2021, No. 2816-r). Moscow, 2016. (In Russ.). Retrieved from https://www.garant.ru/products/ipo/prime/doc/4 02792803

[17]V.E. Seliverstov, "Strategic planning and strategic errors: Russian realities and trends", Regional Research of Russia, 2018, vol. 8(1), pp. 110-120.

DOI: $10.1134 / \mathrm{S} 2079970518010082$

[18]P. Śleszyński, "Strategic intervention, problem and functional areas in national and regional strategic documents", Studia Regionalne i Lokalne, 2020, vol. 79(1), pp. 30-59.

[19]E.M. Buchwald, "Institutional problems of spatial development strategies in Russia", Journal of the New Economic Association, 
2019, vol. 2(42), pp. 121-136. DOI: $10.31737 / 2221-2264-2019-42-2-6$

[20] A.V. Sidorenko, N.G. Sirotkina, "Social policy as a factor of economic development of the region" ["Sotsial'naya politika kak faktor ekonomicheskogo razvitiya regiona"], Vestnik of Samara State University of Economics, 2017, vol. 1, pp. 43-51. (In Russ.).

[21]B.S. Zhikharevich, V.V. Klimanov, V.G. Maracha, "Resilience of a territory: concept, measurement, governance", Regional Research of Russia, 2021, vol. 11(1), pp. 2-8. DOI: $10.1134 / \mathrm{S} 2079970521010135$

[22]E. Kazantseva, N. Osokina, G. Chistyakova, "Prospects for social and economic development of coal mining regions", E3S Web of Conferences, 2020, vol. 174. DOI: $10.1051 / \mathrm{e} 3$ sconf/202017404021

[23]E. Pastukhova, E. Morozova, A. Mukhacheva, N. Egorova, "Public health as the indicator of regional socioeconomic development",
Advances in Economics, Business and Management Research, 2019, vol. 83, pp. 188191.

[24]E. Morozova, A. Mukhacheva, T. Dobrydina, N. Usvyat, "Recessive social trends in the coalmining region (on example of Kuzbass) as a barrier for sustainable development", E3S Web of Conferences, 2018, vol. 41. DOI: 10.1051/e3sconf/20184104029

[25]E. Morozova, E. Pastukhova, T. Logunov, "Demographic problems as hindrance for sustainable development of a mining region (the case of the Kemerovo region)", E3S Web of Conferences, 2020, vol. 174. DOI: 10.1051/e3sconf/202017404044

[26] Yu.N. Svinukhova, "Social development of the region: theoretical and methodological aspects" ["Sotsial'noye razvitiye regiona: teoretikometodologicheskiye aspekty”], Concept, 2018, vol. 9, pp. 254-262. (In Russ.). DOI: 10.24422/MCITO.2018.9.16674 